\title{
"Deeply Human, Fundamentally Social": Fascism and Internal Colonization in Badajoz Province during the Early Franco Dictatorship
}

\section{"Profundamente Humano, Fundamentalmente Social": Fascismo e Colonização Interna na Província de Badajoz no Início da Ditadura de Franco}

\author{
David Henderson, \\ University of California San Diego, USA
}

\begin{abstract}
This article explores the ambition of the Franco regimes National Institute of Colonization (INC) to remake the countryside through irrigation and settlement. It focuses on the human side of this project, arguing that Spains colonization effort was fundamentally fascist in its aim to ensure the success of a nationalized and politically loyal segment of the rural population. It argues that the agricultural engineers of the INC inserted themselves as paternalistic authorities in the countryside, managing a carefully chosen portion of the peasantry. As the INC worked to begin its large-scale colonization schemes in the 1950s, it sought to determine which towns suffered from a social problem caused by the unemployment of tenants and small-property owners rather than landless laborers. In spite of the technical rhetoric of the engineers, with their stress on productivity and rationalizing land use, this article will demonstrate that certain political and moral considerations remained paramount throughout the process.
\end{abstract}

Keywords-Colonization; Irrigation; Spain; Fascism; Modernization.

Resumo-Este artigo explora a ambição do Instituto Nacional de Colonização (INC) do regime franquista para reconstruir o mundo rural através da irrigação e colonização. Centra-se no lado humano deste projecto, argumentando que o esforço de colonização de Espanha foi fundamentalmente fascista no seu objectivo de assegurar o sucesso de um segmento nacionalizado e politicamente leal da população rural. Argumenta que os engenheiros agrícolas do INC se inseriram como autoridades paternalistas no meio rural, gerindo uma porção cuidadosamente escolhida do campesinato. Enquanto o INC trabalhava para iniciar os seus esquemas de colonização em grande escala nos anos 50, procurou determinar que cidades sofriam de um "problema social" causado pelo desemprego dos rendeiros e pequenos proprietários, mais do que dos trabalhadores sem terra. Apesar da retórica técnica dos engenheiros, com a sua ênfase na produtividade e na racionalização do uso da terra, este artigo demonstrará que certas considerações políticas e morais permaneceram primordiais ao longo de todo o processo.

Palavras-Chave-Colonização; Irrigação; Espanha; Fascismo; Modernização.

Submitted-04-08-2021. Accepted-08-11-2021. 


\section{Introduction}

Z or Ismael Saz, Franco's regime was charI acterized until its late stages by opposition between two internal ideological poles (Saz 2007). One pole had its base in the church and military and sought to keep the population depoliticized, while holding onto traditional elements - the Catholic Church, the monarchy - as legitimating institutions. It was opposed by Spanish fascism, anchored in the Movimiento Nacional, the only political party allowed under the dictatorship, which sought popular mobilization. While leaders of both ideological currents pushed for economic modernization, Spanish fascists aimed to have economic growth serve the purposes of a "third way" political-social agenda between capitalism and socialism. Landscape transformation through a combination irrigation and internal colonization proved to be one of the most important elements of this agenda. As in Italy under Mussolini (Armiero 2014), the transformation of the landscape in Francoist Spain was aimed at refashioning the population beginning with a chosen, limited minority of new Spaniards. The regime feared the socialism and anarchism that had animated much of the rural population during the 1930s and hoped that using irrigation to create new Spaniards from a class of responsible, smallproperty holders would be the germ of political enthusiasm for the regime in the countryside. These concerns led to concentrated colonization efforts in areas such as Extremadura in southwestern Spain where rural political conflict had been sharp and irrigation was possible.

Scholars of the Franco regime have argued for some time about whether to consider it fascist, authoritarian, or a hybrid type of government that transformed as technocrats eclipsed the Movimiento in power (Radcliff 2017). Those who have argued against the fascist label for the regime (such as Paxton 2004) as a whole or for the set of landscape and settlement policies considered here claim that the regime left traditional elites in power and, in the case of rural Spain, hesitated to expropriate significant amounts of land from

\section{- David Henderson,}

E-mail:dkhender@ucsd.edu

DOI:http://dx.doi.org/10.21814/perspectivas.3088 large landlords until the end of the 1940s when the power of fascists within the government had begun to wane (Riesco 2020). However, strategic compromises and limited social transformation should not be surprising given fascism's malleability. In spite of fascist parties' socially ambitious written programs, Paxton points out that "once in power, fascist regimes confiscated property only from political opponents, foreigners, or Jews. None altered the social hierarchy except to catapult a few adventurers into high places". What did make the internal colonization policies of the early Franco regime fascist was the pursuit of extreme nationalism through a social program aimed at both control and the transformation of a chosen minority. They evinced an ultra-nationalistic concern for the integrity and reconstruction of the national community (Griffin 1995).

Choosing land transformation, irrigation and settlement as a means of nationalizing citizens was not accidental. Unproductive agriculture had been assigned the blame for Spain's decline since the seventeenth century (Ringrose 1995). Charles III had ordered the construction of agricultural colonies in Andalusia in the eighteenth century. Irrigation became a prominent political issue when Joaquín Costa, a politician and public intellectual, called for the transformation of the Spanish countryside through irrigation after defeat in the Spanish-American War (Costa and Ortí, 1975). Costa's ideas irrevocably tied the revitalization of Spain to the exploitation of its water resources. The political prominence of irrigation prior to the Spanish Civil War has led some scholars to posit continuity between the Regenerationist movement or Catholic intellectuals opposed to radical land reform and Franco's enthusiasm for irrigation. I argue here with Ismael Saz, however, that the ideas of the generally liberal Regenerationists were "sliced and manipulated" to fit the projects of the Franco's ministers (Saz 2007). This was particularly the case with irrigation and internal colonization as fascist influence turned irrigation from primarily an economic program motivated by an abstract nationalism into a specific moralpolitical program designed to encourage adherence to the regime and provide patronage to a select segment of the peasantry. 


\section{Colonization: the Human Aspect}

The Franco regime created the National Institute of Colonization (INC) within the Ministry of Agriculture in 1939 in order to address problems of unemployment in the countryside (BOE 1939). It was a response to the land reform efforts of the Second Republic, which had embarked on a classical land reform program based upon expropriation from large landowners in targeted provinces such as Badajoz and redistribution to landless laborers (Carmona and Simpson, 2020). The INC was primarily designed to settle internal colonists, who would become tenants of the INC, on newly irrigated dry land or reclaimed wetlands in large projects patterned after Mussolini's land reclamation and town construction projects in the Pontine Marshes. As opposed to the Italian bonifica integrale, the Franco regime chose not to antagonize landowners with large-scale expropriation until the 1949 (Riesco 2020). It also had a mandate for small-scale local colonization efforts that would prevent existing tenants in danger of eviction. In lieu of resolving seasonal and permanent unemployment of landless laborers as the Second Republic's land reform had attempted, the INC aimed to benefit those it deemed likely to be enthusiastic adherents of the regime. Therefore, tenants and small property owners were the intended beneficiaries of colonization.

The first director of the National Institute of Colonization, Ángel Zorrilla Dorronsoro, articulated a policy that rejected the land reform of the Second Republic and capitalism, which the Falange, the Spanish fascist party that was merged with other right-wing movements into the single political party allowed under the regime, understood as without spiritual or ethical values (Zorrilla 1941). The modernization of a nation had to consist of "grades of development: spiritual, political, and, consequently, economic" (Zorrilla 1941). The INC's settlement and supervision of colonists served these moral and political ends at a time when the regime unconvincingly blamed international isolation and scattered guerilla warfare in the aftermath of the Civil War for the widespread hunger of the 1940s (Hernández-Burgos 2016).

The early INC was imagined as a military organization bringing political order to a chaotic countryside. The INC organization was at first patterned after a military organization with a series of brigades across the provinces that responded to the direction of the Director General. Its local chief engineers were ordered to maintain the highest moral standards in private as well as public matters. The regime dabbled in ruralism similarly to Fascist Italy and Nazi Germany: promoting the countryside as the heart of the Spain's strength in propaganda while viewing it as a space in need of control (Armiero 2011). The director general asked brigades to visit as many of their districts as possible and to always protect themselves from the countryside, the "anti-thesis" of the real Spain (Circular N. 15, 1941). Contact with the peasantry in the countryside threatened to "degenerate" the spiritual lives of his agricultural engineers. Brigades were encouraged to cultivate a lifestyle that included elite recreation such as hunting and sport.

INC workers, even office workers, were screened carefully for their political activities. The Institute offered previous office employees of its predecessor agencies, including the Institute of Agrarian Reform, the opportunity to reapply for jobs with preference over other applicants. However, they had to make sure to officially reapply and also to provide documentation of their "political-social" conduct from the Ministry of Agriculture, other official state institutions, or the FET-JONS. A handful of employees were immediately fired for a variety of causes including: serving in the Red Cross for the Institute of Agrarian Reform, fighting with the Republican side in the Civil War, being a member of the Left Republican Party during the Second Republic, being a freemason, and joining the Institute of Agrarian Reform after the Popular Front had triumphed at the polls (BOE 1941). While this was no different than other state agencies following the Civil War, it did guarantee that the INC's project was tied to its specific political ideology at a time when fascism held the upper hand over National Catholicism.

Before settlement could begin, agricultural engineers had to first study the regions that needed state assistance, with special attention paid to the classification of land with an eye towards possibilities for irrigation or reclamation. They 
also had to report on an area's agronomy, the legal status of relevant properties, level of unemployment, and cultural (educational and religious) facilities (Circular N. 5 1940). This process made "the brilliant vision of the Founder of the Falange concrete through exact technical rules" by determining the proper "unidades de cultivo", the minimal plot sizes to support the large families who would be the beneficiary's of colonization (Circular N. 27 1941). Action would be taken if the INC determined that the land could support more tenants through rationalizing crops or supplying more fertile land.

Not just anyone could be selected as a colonist of course. The list of preferred requirements for colonists consisted of the following: they had to know how to read and write, be between 23-50 years old (unless one had served in the military), be married or widowed with children, be able to demonstrate agricultural proficiency, have no hereditary illnesses or physical defects (syphilis, tuberculosis, alcoholism), and have a record of good conduct and morality. The more children one had, the more likely one was to be chosen as a colonist since one could better serve to increase the population of Franco loyalists. These series of requirements demanded that a careful selection of colonists be carried out, a selection that would do as much as possible to weed out unfit colonists. Colonists, in order to move out of the system of "tutelage", had to earn their freedom of decision. In the "formation" classes for all colonists, they were not only to be taught practical agricultural skills, but moral and social lessons that would guarantee attention to the religious, health, and intellectual subjects necessary for a strong moral environment. These lessons would be reinforced by the spread of model farms - where successful families would be installed with the best supplies that the INC could afford. Being in the presence of these model colonist families would give new colonists a sense of what was possible.

The guiding tenets of the INC were formulated in the Revista de Estudios Agro-Sociales and in conferences on colonization by a series of agronomists in the Ministry of Agriculture. They helped to ensure that the labor of colonization would be "deeply human, fundamentally social" (Martínez 1944). One agronomist argued in 1944 that what the INC had to do was create a select group of farmers. He started by demanding that his readers not forget that the "goal of colonization, and at the same time its principal agent, is man". This man had to be linked to his nation, his patria. Without a sense of his belonging to Spain, the INC worried that a man would lose his identity and allegiance to the re-founded nation. The purpose of colonization, then, was "rescuing socially useful men for the common destiny of the Nation; uniting men of the countryside to the land that absorbs their efforts; linking the laborer with his fields, allowing him a dignified and progressive individual and social life". This group, who would be independent, morally upright and have a number of skills, would ideally bring stability to a countryside that had seen to be in political conflict during the Civil War and Second Republic. The ownership of a plot of land by a true "laborer", as opposed to factory work or menial laborer, meant that he had to master the climate, the land, crops and the appropriate treatment of animals. These skills were "broader, noble and more humanistic" than the unthinking operation of machinery in a factory. This property-owning life was much to be preferred to that of "those undifferentiated troops of population that fuel tumultuous mass movements" (Martínez 1944).

Another agronomist candidly stated that colonization was designed as a selection process, meant to end with a small group of responsible subjects (Gomez 1944). Even after the most careful selection of colonists, $40 \%$ should never make it through the preparation and settlement process to become true property owners, according to him. After the selection, then, potential colonists required a period of "vigilance" and "tutelage" when the INC would make decisions for them until colonists' had paid off their debts to the INC for assistance and irrigation. The outlined program, which was adopted by the INC, was one where the colonists were placed squarely under the institute's authority in a situation akin to sharecropping. Over the five years of the tutelage period the colonists had to pay back the cost of the initial livestock and farm materials provided to them by the INC. The repayment schedule was not up to the colonist; he was to repay the INC in the form of $20 \%$ of the harvest during 
the first five years of land occupation. If the payment in terms of crops had exceeded that of the INC investment in equipment and livestock, then this amount would be counted as the first down payment towards the colonists' real debt: the property itself. Once the first five years were up, if the colonist had lived up to his obligations by caring for his plot of land, house, and animals and had paid off his debts to the INC (if he had not, then that debt would be added to the price of the property), the period of attaining property would begin when colonists gained the titles of their houses and lots and could begin making mortgage payments. Lest this system actually be seen as too generous to colonists, the author reminded his readers that the INC possessed an "unquestionable authority" over colonists due to their debt and legal status. They could be fined or expelled for a number of reasons. And he also outlined the strict obligations that colonists had to care for their plot, as well as their equipment and livestock. In fact, each had to devote "all of his work, and his family's" to the plot. Besides the attention paid to their plot of land, the INC expected colonists to keep up a "strong sense of morality, completion of their family obligations, a sense of decorum in their lives, and noble usage of their home" (Gomez 1944). In this way, the program adopted to manage colonists throughout the lifetime of the INC and took as its main aim the creation of new Spaniards.

\section{Early Colonization in Badajoz Province: Tenants and Veterans}

In practice, the fascist emphasis on moral transformation through property administration concentrated INC activity in areas where land reform had been an explosive issue during the Second Republic. The Badajoz Province, because of its poverty, size, hydrography, history of social unrest and low population density, became a principal object of INC action, and it was one of the first areas to be declared of "national interest", the initial step in allowing the INC to take action. With a history of rural activism, it was the site of some of the fiercest political conflict concerning land reform during the Second Republic, when it was one of the provinces targeted by the Land
Reform Law of 1932, and then became subject to violent Nationalist repression during the Civil War. Located above Seville, it stretches from the border with Portugal to the edge of Castilla-La Mancha region at its Ciudad Real province. The Guadiana River runs east to west all the way across the province before plunging south at the city of Badajoz and becoming the border with Portugal. The dehesa landscape of much of the area, made up of cork oaks and pasture, along with the dry secano farmland, made it appealing to INC officials who saw rationalizing land use, as well as irrigation, as the key to modernizing the peasantry. Eucalyptus forests and irrigation canals were much to be preferred over the wildlooking dehesa (Pinto-Correia et al, 2011). Eventually it became the object of the Plan Badajoz, a regional irrigation, electrification and settlement project patterned after the Tennessee Valley Authority. The groundwork for the settlement aspect of this project was undertaken in the 1940s as the INC determined its method of action and intensively studied the province. Before it began settling colonists in large zones, the INC had settled 3,720 colonists on 42 farms in Badajoz (Pérez Rubio 1995). ${ }^{1}$

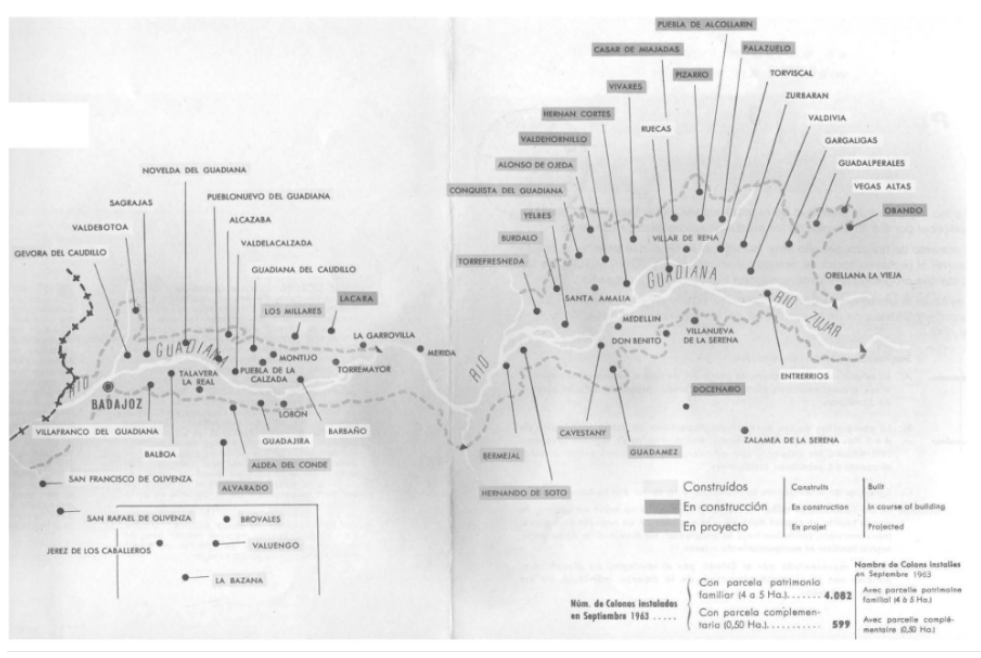

Figure 1: Towns of the Plan Badajoz. Carlos Romero Cuadrado, Aspectos económicos ligados a las explotaciones creadas por el Plan Badajoz (Madrid: Universidad Politécnica de Madrid, 2007), Appendix.

1. Using 1950 as a rough cut-off date. 
The first responsibility of the INC in Badajoz was administration of farms acquired by the Republican and Primo de Rivera governments. Its political mission was immediately apparent: hopeful colonists correctly understood the INC as an instrument to reward those who would be loyal to the regime. Almost all early applicants wrote to the INC to either reclaim property that was lost during the Civil War because of Nationalist sympathies or to make claims for property based on their service in the Civil War.

In Jerez de los Caballeros, the INC was faced with the task of sorting out various claims to tenancy on the three farms under its control that had first been settled during the Primo de Rivera dictatorship (Carmona and Simpson 2015). One potential colonist noted that he had lost his plot only because of service on the Nationalist side in the Civil War when he had felt "the enthusiasm for sacrifice proper to every Spaniard who felt the crisis and danger through which Spain passed in those days". If the INC were to reinstate his family as tenants, protecting his mother, it would bring "consolation to a Spanish hearth and bread to a poor, sick old woman with no resources" (Carrasco to INC 1944). Another potential colonist claimed to have been harassed during the "red period" because of his politics (de la Cruz to INC 1943). Supposedly he had not been allowed to retake his plot because he was "boycotted for being a man of order". Six hopeful colonists all asked for land at a farm near Lobón and all were careful to advertise their status as Civil War veterans (Guerrero 1943, Álvarez 1943, Martín 1943, Torres Cabañas 1943, Torres Martín 1943). A few noted that they had been wounded, and others that they were fathers of large families, a designation created by the pronatalist Francoist government and a key criteria for potential colonists. One claimed he "had heard that the Institute was dividing [the land of] the Castillo de Guadajira with wounded veterans preferred above all others" (Torres Martin 1943), while another wrote to the chief engineer that he had "news that veterans certified as fathers of numerous families were being given plots by the National Institute of Colonization" (Martín 1943). Of thirty petitions sent between the years 1943 and 1944 concerning these two farms only five were not from veterans. All of the applications demonstrate that INC assistance was targeted at specific sections of the population: those who had suffered at the hands of the "reds", veterans of the nationalist side (applicants were sure to highlight any medals they possessed or wounds they had received), and fathers of large families. Applicants were careful to include certifications of their political and moral conduct by persons in positions of authority - priests, city hall officials, civil guards or, in special cases, the watchmen of farms.

These efforts make clear that potential colonists and those concerned for them saw an implicit political promise in the duties of the INC. It was designed to reward loyalty to the Nationalists. Carmé Molinero has written of how the regime framed its social proposals in terms of charity rather than duty to citizens (Molinero 2005). State aid preserved the idea of a hierarchical society - Spanish subjects had more duties than they had rights. The same is true of colonization. The only segments of the population who felt they had the strength to make claims on the government were those who could demonstrate loyalty to the Nationalist cause.

Besides administering its own farms, the INC also tried to protect tenants, particularly tenants who had their own farming capital. In Badajoz, plowmen (yunteros) were an important part of the region's economy, being responsible for the clearing of land that doubled the farmland under cultivation from 1900-1930 (Riesco 2009). They became political symbols of the desire for land reform in Extremadura because of their discontent with landowners who turned their lands over to pasture during the 1930s and their role in the occupation of private farms, particularly in March of 1936. They came to represent all of those who worked under the leasing or sharecropping contracts that were widespread in Extremadura and necessary for the exploitation of dehesas. In spite of their political radicalism, they became the object of regime interest and protection. These were not the landless laborers who the INC disdained, they owned capital and were connected with the land, and could thus be part of the redemption of the countryside that had been so sympathetic to the Republican side in the Civil War.

The regime demonstrated its special care for 
tenants, as opposed to landless laborers, with a series of laws designed to prevent tenants from eviction and rent raises (BOE 1940 and BOE 1942). Local cases of eviction could reach national importance. In Santos de Maimona, a small town in the southeastern portion of Badajoz Province, olive and vine-growing tenants from a number of farms fought their evictions for more than seven years leading, to the eventual intervention of the INC (García 1948). The tenants would not go along with the eviction order and took their case to court in 1941, winning through the provisions of one of the regime's tenancy laws. In 1945, two other trials in nearby towns resulted from attempts to evict similar tenants. Franco himself was informed of the cases by the mayor of Santos de Maimona in December of 1945, and, as a result, the evictions of all tenants who cultivated olives, vines or orchards were halted (BOE 1946). Eventually the case, as well as all other pending disputes over olive, vine or orchard contracts in Spain, was regulated by a new law that continued to protect these special tenants but allowed for the recalculation of rents based on the productivity of the farm and normal rent prices in the locality (BOE 1946).

The passing of this law caused the case for eviction to be thrown out, and the tenants of all three farms were able to keep their land, but it allowed rents to be raised enough to worry the INC. It carried out a study of Santos de Maimona to see if the evictions would result in a "social problem" warranting local colonization. The 53 total tenants clearly could not pay the new rent according to the INC's report of 1948 (García 1948). In order to maintain the town's equilibrium, which meant limiting unemployment in the face of a large increase in rent, expropriation was necessary. The chief engineer of the Guadiana delegation of the INC commented on his engineer's study, emphasizing that the tenants had improved the land by planting olives and vines, thus serving the national interest. Moreover, there was no hope of these colonists finding a place on other farms in the region since the three nearby farms over 100 hectares were "pasture and labor" dehesas instead of vineyards with no new land to be put under cultivation. In May 1949, the INC expropriated one entire farm and the parts occu- pied by tenants in the other two, to ensure that these tenants literally enjoyed the fruits of their labor (García 1948). These tenants were all "good workers" and "honest and humble" peasants of good political-social character. More importantly, they had improved the land themselves through the planting of vines, confirming the ideology of the regime that private initiative by the right individuals, when given a stake in the outcome, would naturally begin productive changes and defend the nation under reconstruction.

\section{Yunteros: the Solution to Badajoz's "Social Problem"}

The idealized, yeoman-like yuntero remained the object of the INC's colonization projects over the course of the regime. Before the INC could take action it had to perform social studies of towns that were nominated by a provincial junta made up of local notables that explicitly prioritized the needs of yunteros. In one section of the provincial Plan published in 1948 that resulted from the first round of social studies, the Junta presented a "social history" of the province. It identified the present-day social problem as the existence of "thirty-five thousand yunteros who do not possess sufficient land". They were accompanied by "sixty-six thousand simple braceros" (Badajoz 1948). The simple braceros, the landless laborers, could not be counted on to lift themselves out of poverty; they had to wait for later industrialization to attract them out of towns. But the 35,000 yunteros were understood by the INC as those who possessed some means of production or small property but still had to lease land as tenants. Their small plots of land did not "absorb all of their labor capacity". It was this class, as underutilized as Extremadura's natural resources, that had "the strength, perseverance, responsibility and initiative" to leave poverty behind and was the key to the area's political future (Badajoz 1948).

The Junta's responsibility to commission INC social studies elicited a correspondence from the municipal authorities of the Badajoz Province. Mayors, likely to be sympathetic to the social ideals of the Falange because they were appointed by the regime, urgently sought action to cure the 
unemployment of yunteros (Pérez 1995). Local officials or priests proved themselves to be able interpreters of the Junta's concern for the political status of the countryside. The mayor of Casas de Don Pedro explained that "THREE HUNDRED AND TEN" yunteros came to the local office of the state-led agricultural union to ask for land each day. In May 1950 he wrote to the Junta: "this is the problem that we have seriously before us, to find land in order to go about converting these humble yunteros into property owners, rapidly lessening their numbers until they've disappeared, which will be the day when Franco's word will have come true and the land will be at the service of the Spanish people, and a step will be taken towards the subordination of the economy to politics". If economic growth could be widely shared, "the strength of rural workers' bonds to the institutions of the state will increase exponentially, creating another tool to achieve social tranquility and peace" (Villares 1950). In September 1950, the priest of Mirandilla, appealed directly to the chief engineer of the INC for the Guadiana region. The priest wrote to remind him of the four hundred yunteros from Mirandilla who had been waiting for several farms to be parceled out to them. There had been a conflict running since 1946, when a landlord had sought to evict the tenants on his land, unilaterally ending their contracts. The tenants refused to leave and continued to farm the land while the landlord fought back by bringing in livestock to ruin their field. After a first hearing and a favorable response from the INC to their request for expropriation of the farm, "there had been only the deepest and most impenetrable silence". He went on: "These robbed men who have an aptitude for work and the largest desire to elevate their quality of lives, will be converted, without a doubt, into our worst enemy, into revolutionaries. And I believe they have good reasons [to do this]" (González to INC 1950). Here, he demonstrated his understanding that the real fear of local authorities was that those who could be made into loyal supporters of the regime might turn away from it politically due to inaction.

In its studies, the INC sought to determine how large of a population each town could support with its agricultural land fully exploited. Agricultural engineers were sent to collect informa- tion on towns' demographic, cultural, agricultural and economic situations. Economic growth would come from the INC's technical intervention; the INC believed that the land was not adequately exploited. The "social problem" had to be met through the "intensification" of agriculture. The technical framing of the problem hid the usual political agenda. There was an anxiety shared by the regime about the political consequences of unemployment. Yunteros, had to be supported so their potential support for the regime could be tapped into, much as the region's agricultural and hydrographic resources needed to be more fully utilized. An ideal rural landscape emerges from the INC's studies where ownership and cultivation of the land would lead to socially tightknit communities. The INC used this ideal community as a template to restructure towns and villages, believing that adjusting the inequality of land-ownership would mitigate yuntero discontent. Through state intervention, the regime sought to create the physical and economic circumstances for social harmony, to defuse political unrest, and to ultimately secure the countryside for Franco by supporting a new class of landowners.

In most cases, the engineers aimed to expropriate and reorganize an adequate number of farms to guarantee employment for yunteros. In both Cabeza del Buey and Campanario, two rural towns in the province, agricultural engineers were sent to collect information on demographic, cultural, geographic and economic situations, combining this information with that available in state, provincial and municipal archives. Jacinto Terrón was sent to Cabeza del Buey in 1947, Jesús Castañon to Campanario in 1949. In the studies, agricultural workers were divided up into those who owned property and cultivated it, those who owned sufficient property to support their families but also augmented the income from their property by working as braceros or leasing other land, those who worked in agriculture and had mules or other means of production but little or no property (yunteros), those who had permanent jobs as agricultural workers, and those who held no property (simples braceros). Between 380 and 500 men were unemployed depending on the season in Campanario, leaving at least $30 \%$ of the male working population unemployed at these times. 
Some braceros visited other towns for work, but their number was discarded as negligible. Cabeza del Buey and its surrounding villages found itself in a similar state. It was mired in even worse permanent unemployment than Campanario with $44 \%$ unemployed in the town and $60 \%$ in the town's outlying villages during various parts of the year. All of this unemployment resulted from an "excess of labor for the capacity of the local market", caused by the insufficient distribution of property (Terrón 1947). For the INC, work and property were directly linked; the key to fixing the unemployment problem would be to increase property ownership, which would naturally boost production (or at least agricultural cultivation at the expense of livestock-raising) as small owners would fully exploit their plots of land. It was the same calculus as that of the Second Republic's land reform program except now the INC only sought to remedy the unemployment of a carefully chosen segment of the rural population.

The agricultural engineers went in search of large concentrations of land, which they believed to be inherently inefficient and the cause of unemployment. Landownership was concentrated in both Campanario and Cabeza del Buey proper (excluding its surrounding cities). In Campanario, those who owned more than 100 hectares (about 250 acres) were in possession of $75 \%$ of all property. Those owners averaged 465 hectares; those who owned less than 100 hectares averaged 3.9 hectares (Castañon 1949). The story was the same in Cabeza del Buey where only the land directly to the south of the town was divided up into small parcels. The 94 owners who possessed more than 100 hectares between them totaled almost 40,000 hectares leaving less than 7,000 for the remaining 1,555 owners. Terrón also made sure to compare the numbers of absentee landlords to local ones. Although residents of Cabeza del Buey owned most of the largest farms, Terrón was keen to investigate the role of absentee landlords in reinforcing the "social problem" of the town (Terrón 1947).

To solve the unemployment of yunteros, large farms were targeted to be partially or fully expropriated and settled by yunteros as colonists. The farms targeted for forcible state purchase had to meet a number of criteria. Preferably they would be owned by absentee landlords, located on good quality soil, close to potential hydraulic works, large enough to divide up into many plots and be currently devoted to a mix of livestock-raising and agriculture. Castañón proposed the expropriation of two farms in Campanario, La Hoya and Umbriazo, totaling 1,017 hectares between them in order to settle 150 of the town's 186 yunteros (Pérez 1995). The farms united a series of characteristics that made them particularly attractive for expropriation. Their soil was of secondary quality, which was irrigable. The owner of La Hoya, a woman of the petty nobility, was absent from the property and therefore not a contributor to the town's community life. The owner's absenteeship was highlighted several times; she could never be found and was contacted through a farm guard. Land was leased through sharecropping or rental contracts, and livestock, seen as less productive and less labor-intensive (making it useless in combatting unemployment), was a large part of the operation. In the end neither farm was ever expropriated. Similarly, Terrón's vision of the source of the social problem in Cabeza del Buey came down primarily to the concentration of property in a few (often absentee) landlords. These landlords also raised livestock on significant parts of their farms. In Cabeza del Buey, where the problem was more insurmountable, the expropriation and colonization of six farms was called for (Terrón 1947). Here, unlike in Campanario, the expropriation of these six farms was carried out, and they were settled in 1950 (Pérez 1995).

The studies, taken together, demonstrate the INC was acting in the Badajoz region in the interest of guaranteeing politically stable communities. Both reports hint at the fear of unrest and anger on the part of the yuntero population. Terrón wrote: "there exists a discontent amongst the mass of agrarian workers, particularly those who possess some means of production [yunteros], caused by the excessive concentration of land" (Terrón 1947). So although the root problem was unemployment, the INC really feared the political fallout from it. The understanding that absentee landlords would certainly be more concerned for the towns' social problems if they were present confirms this. The solution to the social problem was uniformly the intensification of local agricul- 
ture for yunteros combined with the prospect of future jobs provided by later hydraulic projects for braceros (although the reports ignored that yunteros would also be preferred in these future settlement projects).

Organized, parceled up farms were much more desirable than wild dehesas. Any farm not divided up into parcels, especially if it was owned by an absentee landlord, could be subject to expropriation. In photos attached to the appendix of the Cabeza del Buey study, Terrón pointed out the border between two farms, one with the scattered brush and trees of the dehesa landscape typical of the region, while the other was made up of neat lines of crops.

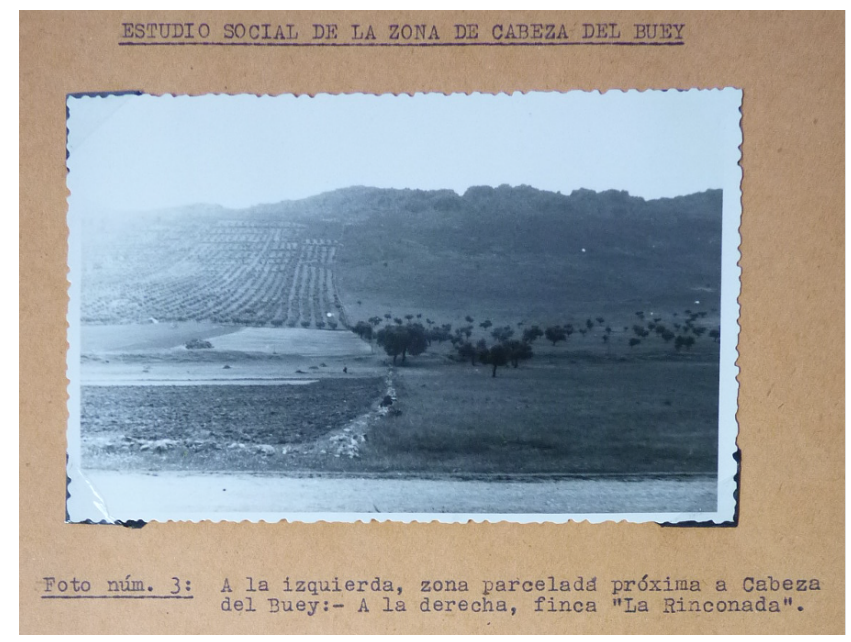

Figure 2: The Rinconada farm, declared to be of "national interest", in February of 1949, compared to an organized farm. "Terron, Estudio social del Término de Cabeza del Buey", AHCEA.

The preference for parceled land was not due primarily to its improved economic performance, rather, many more workers were required than for the raising of livestock. Livestock-raising "deprived those plowmen of the only lands within the town's limits where they could employ their energy" (Terrón 1947). In Cabeza del Buey, the Director General of the INC even ordered that, although the amount of land ultimately expropriated was less than called for, the number of settled colonists be kept the same (decreasing lot size) to ensure the greatest number of property owners (Montero 1947).
A new class of direct cultivators would be politically reliable contributors to national wellbeing. The director of the INC noted, in his approval of the study of Cabeza del Buey, that the usual producer lives off of his own physical efforts and "is a hard worker and has great affection for the land, and along with it, enthusiasm for his profession" (Montero 1947). Still the expropriation proposed at the end of each study never aimed to employ the entire population. In each case, proposals left the numbers of unemployed braceros the same. This population did not appear responsible or hardworking enough to the INC to be worthy of urgent local colonization projects. Fixed to the land through property ownership, yunteros could be incorporated into communities under the watch of larger, direct landowners, and attended to culturally and religiously. Their responsibility, exhibited by their ownership of "means of production", made them preferred candidates to be converted into the beginning of a new countryside.

\section{Conclusion}

The INC eventually set aside its enthusiasm for settling as many yunteros as possible on a given piece of land as more technocratic officials took charge of the Ministry of Agriculture and made productivity, instead of total production, the touchstone of its efforts. But until the end of the Franco dictatorship, the INC's colonization program took as its object the creation of new Spaniards through the transformation of the landscape. A selective targeting of regime social policy became even more restrictive. The control and paternal supervision of colonists continued through debt, fines and surveillance even as colonist rebellion to the INC grew over time (Siguan 1963). After the transition to democracy, the Badajoz Province that had seen so much colonization voted with the Socialist Party.

The combination of control and a preoccupation with national identity were the fascist hallmarks of Spain's modernization under Franco. While governments across the twentieth-century particularly dictatorships - used irrigation, dambuilding and land reclamation to build legitimacy and demonstrate modernizing accomplishments (McNeill 2000), fascist modernization can per- 
haps be distinguished through its intense state supervision of a chosen minority meant to help re-found the nation. The concern for national feeling among the beneficiaries of modernization projects ties Spain to the experience of other modernizing fascist dictatorships such as Italy (Caprotti 2008). Encouraging popular adherence to the regime drove fascists and separated them from technocratic and traditionalist programs, but so did an unwillingness to antagonize property owners and an obsession with national purity, leading to a peculiar program where a relatively small group was placed under close state supervision in order to reflect the nationalizing power of a fully exploited landscape. The environmental upshot of colonization in Spain was a completely transformed and more fully exploited landscape with a limited number of beneficiaries. The traditional oak savannah of the dehesa with its mixed uses has given way to large agro-businesses in the lands surrounding irrigation projects (Palacín 1977). The social goal behind colonization, the creation of a small group of enthusiastic transformed Spaniards, justified expansive irrigation projects and state investment in mechanization that left the majority of the rural population untethered. Colonization and the Plan Badajoz were intended to spur repopulation of the Badajoz Province, but ended up serving to facilitate a massive emigration to Spanish and European cities beginning in the 1950s that has continued since.

\section{References}

[1] Álvarez Dorado, Juan Antonio to Ingeniero Jefe del Instituto Nacional de Colonización. 10 March 1943. Archivo Histórico del Centro de Estudios Agrarios (AHCEA).

[2] Armiero, Marco. 2014. "Making Italians Out of Rocks: Mussolini's Shadows on Italian Mountains". Modern Italy, 19(3): 261-275.

[3] Armiero, Marco. 2011. A Rugged Nation: Mountains and the Making of Modern Italy. Cambridge: Cambridge University Press.

[4] Campos Palacín, Pablo. 1978. "La crisis de la dehesa tradicional y la degradación de las recursos naturales en Extremadura". In Extremadura Saqueada : Recursos Naturales $Y$ Autonomía Regional, 515-542. Barcelona: Ruedo Ibérico.

[5] Caprotti, Federico and Maria Kaïka. 2008. "Producing the ideal fascist landscape: nature, materiality and the cinematic representation of land reclamation in the Pontine Marshes". Social and Cultural Geography, 9(6): 613-634.

[6] Carmona, Juan and James Simpson. 2020. Why Democracy Failed: The Agrarian Origins of the Spanish Civil War. Cambridge: Cambridge University Press.

[7] Carmona, Juan and James Simpson. 2015. "Organización y funcionamiento de los asentamientos de la reforma agraria. La comunidad de campesinos de La Pulgosa en Badajoz, 1933-1941". Revista de Estudios Extremeños, 71: 105-128.

[8] Carrasco Vazquez, Manuel to Ingeniero Jefe del Instituto Nacional de Colonización. 27 November 1944, AHCEA.

[9] Castañón, Jesús. 1949. "Estudio Social de Terminó del Campanario". Archivo Central del Ministerio de Agricultura y Pesca, Alimentación y Medio Ambiente (ACMAPAMA).

[10] "Circular N. 5: Instrucciones a las brigadas de información general". 15 June 1940. ACMAPAMA.

[11] "Circular N. 15: Prestigio del instituto y relación con interesados y autoridades", 13 February 1941, ACMPAMA.

[12] "Circular N. 27: Estudio de las unidades de cultivo". 2 August 1941. ACMAPAMA.

[13] Costa Martínez, Joaquín and Alfonso Ortí. 1975. Oligarquía y caciquismo: como la forma actual de gobierno en España, urgencia y modo de cambiarla. Madrid: Ediciones de la Revista de Trabajo.

[14] De la Cruz, Eugenio Basilio to Ingeniero Jefe del Instituto Nacional de Colonización. February 9, 1943, AHCEA.

[15] De Montero y García de Valdivia, Fernando. "Resolución de la Dirección General sobre el Estudio Social de la Comarca de Cabeza del Buey (Badajoz)", 30 June 1947 in Terrón, "Estudio Social del Terminó de Cabeza del Buey".

[16] García de Oteyza, Manuel. 1948. "Estudio del problema social que puede tener planteado el pueblo de los Santos de Maimona, con motivo de la desavenencia existente entre los propietarios cedentes de terrenos baldíos y los colonos que efectuaron en ellos plantaciones asociadas de vides y olivos". AHCEA.

[17] Gómez Ayau, Emilio. 1944. "Tutela, Posesión y Propiedad". Estudios, 3(14).

[18] González Mora Haba, Ángel to Ingeniero Jefe. 4 September 1950. AHCEA.

[19] Guerrero, Alfonso to Ingeniero Jefe del Instituto Nacional de Colonización. 10 March 1943. AHCEA.

[20] Griffin, Roger. 1995. Fascism. Oxford: Oxford University Press.

[21] Hacia la historia social del campo de Badajoz, 1229 a 1947. Desglosado de la memoria del plan general de ordenación económico-social de la provincial. 1948. Badajoz.

[22] Hernández-Burgos, Claudio. 2016. "The Triumph of 'Normality', Social Attitudes, Popular Opinion and the Con- 
struction of the Franco Regime in Post-War Rural Spain (1936-1952)". European History Quarterly, 46(2): 291-310.

[23] Martín Calle, Dionisio to Ingeniero Jefe del Instituto Nacional de Colonización. March 16, 1943. AHCEA.

[24] Martínez Borque, Ángel. 1944. "El hombre y la colonización". Estudios, 3(14).

[25] McNeill, J. R. 2000. Something New Under the Sun. New York: Norton.

[26] Molinero, Carmé. 2005. La Captación de las masas: política social y propaganda en el régimen franquista. Madrid: Cátedra.

[27] Paxton, Robert. 2004. Anatomy of Fascism. New York: Knopf.

[28] Pérez Rubio, José. 1995. Yunteros, braceros y colonos: la política agraria en Extremadura: 1940-1975. Madrid: MAPAMA.

[29] Pinto-Correia, Teresa, Nuna Almeida Ribeiro, and Paula Sá-Sousa. 2011. "Introducing the Montado: the Cork and Holm Oak Agroforestry System of Southern Portugal". Agroforestry Systems, 82(2): 99-104.

[30] Radcliff, Pamela. 2017. Modern Spain: 1808-Present. Hoboken: Wiley Blackwell.

[31] Riesco Roche, Sergio. 2009. "La Cuestión Yuntera En Extremadura Durante La II República". Historia Social, 65: 41-64.

[32] Riesco Roche, Sergio. 2020. "La reforma agraria italiana vista desde España (1918-1953). Un comentario crítico". Revista catalana d'història, 13: 123-145.

[33] Ringrose, David. 1995. Spain, Europe and the "Spanish Miracle", 1700-1900. Cambridge: Cambridge University Press.

[34] Romero Cuadrado, Carlos. 2009. Aspectos económicos ligados a las explotaciones creadas por el Plan Badajoz. Madrid: Ministerio de Medio Ambiente y Medio Rural y Marino.

[35] Saz, Ismael. 2007. "Mucho más que crisis políticas: el agotamiento de dos proyectos enfrentados". Ayer, 68: 137163.

[36] Siguán, Miguel. 1963. Colonización y desarrollo social: estudio en el marco del Plan de Badajoz. Madrid: Instituto Nacional de Industria, Secretaria Gestor del Plan de Badajoz.

[37] Terrón, Jacinto. 1947. "Estudio Social del Terminó de Cabeza de Buey". ACMAPAMA.

[38] Torres Cabañas, Juan to Ingeniero Jefe del Instituto Nacional de Colonización. March 23, 1943. AHCEA.

[39] Torres Martín, Diego to Ingeniero Jefe del Instituto Nacional de Colonización. March 29, 1943. AHCEA.

[40] Villares, Flaviano to Minister of Agriculture. 22 March, 1950. AHCEA.

[41] Zorrilla Dorronsoro, Ángel. 1941. "Política de colonización del Nuevo Estado conferencia dada ante el II Consejo Sindical de la Falange, el día 18 de junio de 1941". Madrid: Instituto Nacional de Colonización.

\section{LEGISLATION}

[42] BOE. 1942. "Ley de 23 de julio de 1942 por la que se modifican algunas disposiciones vigentes sobre arrendamientos rústicos".

[43] BOE. 1940. "Ley de 28 de junio de 1940 por la que se normaliza el régimen de arrendamientos rústicos".

[44] BOE. 1946. "Decreto de 21 de enero de 1946 por el que se crea la Secretaría Genera para la Ordenación económicosocial y se fijan sus atribuciones".

[45] BOE. 1946. "Decreto-Ley de 28 de junio de 1946 por el que se suspende la tramitación de los juicios de desahucio de fincas rústicas dedicadas a plantaciones mixtas de viña y olivar u otras especies arbóreas".

[46] BOE. 1946. "Ley de diciembre de 1946 por la que se dictan normas para los contratos de cesión del suelo para plantaciones mixtas de viña y olivar u otras especies arbóreas".

[47] BOE. 1949. "Decreto de 20 de mayo de 1949 por el que se declara de interés social la expropiación por el Instituto Nacional de Colonización de la finca 'Doña Juana'."

[48] BOE. 1949. "Decreto de 20 de mayo de 1949 por el que se declara de interés social la expropiación por el Instituto Nacional de Colonización de la finca 'Malpuntas'."

[49] BOE. 1949. "Decreto de 20 de mayo de 1949 por el que se declara de interés social la expropiación por el Instituto Nacional de Colonización de la finca 'Valle del Mudo'."

[50] BOE. August 9 1941. "Desestimando instancias de doña Lucía Corrales Ferrás, en solicitud de admisión a los cursillos y exámenes para administrativos del Instituto Nacional de Colonizacion."

[51] BOE. August 9 1941. "Desestimando instancias de los señores que se citan en solicitud de admisión a los cursillos y exámenes para administrativos de Instituto Nacional de Colonización."

[52] BOE. October 27 1939. "Decreto organizando el Instituto Nacional de Colonización."

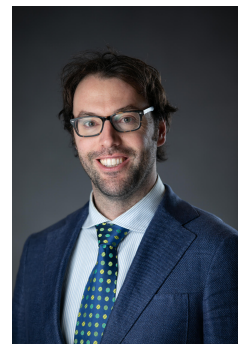

Dave Henderson teachers at Miramar College in the San Diego Community College District. He received his $\mathrm{PhD}$ from UC San Diego in December 2017. His dissertation, El Mar de Extremadura: Irrigation, Colonization and Francoism in Southwestern Spain, 1898-1978, presented a deep history of irrigation in Extremadura and across the Spanish empire. Currently, hes concluding an article on economic change, tenancy contracts and rural political conflict during the first of half of the twentieth century in Southern Europe. 